

PERBANKAN SYARIAH DI INDONESIA

\begin{tabular}{|l|l|l|l|l|l|}
\hline Jurnal & $\begin{array}{l}\text { Nomor } \\
\text { Dialog }\end{array}$ & $\begin{array}{l}\text { Tahun } \\
\text { XXXII }\end{array}$ & $\begin{array}{l}\text { Halaman } \\
137\end{array}$ & Jakarta & ISSN \\
Juli 2009 & 0126-396X \\
\hline
\end{tabular}




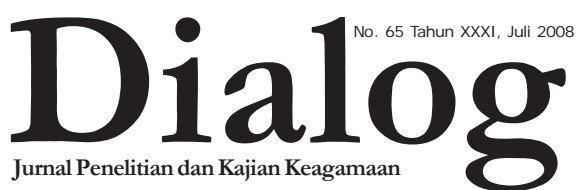

Pemi mpin Umum:

Prof. Dr. H. M. Atho Mudzhar, MA

Redaktur Aht :

Prof. Dr. H. Nasaruddin Umar, MA

Prof. Dr. H. Komarudin Hidayat, MA

Pemimpin Redaksi / Penanggung J awab

Drs. H. Syamsuddin

Waki l Pemi mpin Redaksi

H. Fanani Suprianto, SH., MM

Sekretaris Redaksi

M. Rosyid Fauzi, S.Si.

Dewan Redaksi

Prof. Dr. H. Abdurrahman Mas'ud

Drs. Amin Haedari

Prof. Dr. H. Maidir Harun

Drs. H. Mohammad Shohib, MA

Drs. H. Asmu'i, SH, MM

Chamdi Pamudji, SH., MM

Redaktur Eksekutif

M. Nasir, S.Th.I.

Redaktur Pelaksana

Moh. Rosyid Fauzi, S.Si

M. Nasir, S.Th.I

M. Adlin Sila, M.A

Abbas Jauhari, M.Ag

Admi ni strası

Drs. Dedy Curipno

Sutidjah

Desriyanti Nasution, S.IPI

Drs. H. Sahlani

Alamat Redaksi

Gedung Bayt Alquran Museum Istiqlal Komplek Taman Mini Indonesia Indah

Telp. (021) 87791444-87794982

Website:

www. balitbangdiklat.depag.go.id

Email:

info@depag.web.id

\section{PEIGITIR REDIKSL}

Karakteristik sistem perbankan syariah yang beroperasi berdasarkan prinsip bagi hasil memberikan alternatif sistem perbankan yang saling menguntungkan bagi masyarakat dan bank, serta menonjolkan aspek keadilan dalam bertransaksi, investasi yang beretika, mengedepankan nilai-nilai kebersamaan dan persaudaraan dalam berproduksi, dan menghindari kegiatan spekulatif dalam bertransaksi keuangan. Dengan menyediakan beragam produk serta layanan jasa perbankan yang beragam dengan skema keuangan yang lebih bervariatif, perbankan syariah menjadi alternatif sistem perbankan yang kredibel dan dapat dinikmati oleh seluruh

Jurnal Dialog diterbitkan oleh Badan Litbang dan Diklat Departemen Agama RI, sebagai media informasi dalam rangka mengembangkan penelitian dan kajiaan keagamaan di Indonesia. Dialog berisi tulisan ilmiah dan hasil penelitian dan pengembangan terkait dengan masalah keagamaan. Redaksi mengundang para peneliti agama, pengamat, cendekiawan, intelektual, dan akademisi untuk berdiskusi dan menulis secara bebas serta kreatif demi pengembangan penelitian maupun kajian keagamaan di Indonesia.

2 Dialog No. 67 Tahun XXXII, Juli 2009 
golongan masyarakat Indonesia tanpa terkecuali.

Fungsi Bank Syariah secara garis besar tidak berbeda dengan bank konvensional, yakni sebagai lembaga intermediasi (intermediary institution) yang mengerahkan dana dari masyarakat dan menyalurkan kembali dana-dana tersebut kepada masyarakat yang membutuhkannya dalam bentuk fasilitas pembiayaan. Perbedaan pokoknya terletak dalam jenis keuntungan yang diambil bank dari transaksi-transaksi yang dilakukannya. Bila bank konvensional mendasarkan keuntungannya dari pengambilan bunga, maka Bank Syariah dari apa yang disebut sebagai imbalan, baik berupa jasa (fee-base income) maupun mark-up atau profit margin, serta bagi hasil (loss and profit sharing).

Disamping dilibatkannya Hukum Islam dan pembebasan transaksi dari mekanisme bunga (interest free), posisi unik lainnya dari Bank Syariah dibandingkan dengan bank konvensional adalah diperbolehkannya Bank Syariah melakukan kegiatankegiatan usaha yang bersifat multifinance dan perdagangan (trading). Hal ini berkenaan dengan sifat dasar transaksi Bank Syariah yang merupakan investasi dan jual beli serta sangat beragamnya pelaksanaan pembiayaan yang dapat dilakukan Bank Syariah, seperti pembiayaan dengan prinsip murabahah (jual beli), ijarah (sewa) atau ijarah wa iqtina (sewa beli) (Farouk, 2009), dan lain-lain.
Dalam kajian Jurnal Dialog Edisi ini mencoba menyoroti perkembangan Perbankan Syariah di Indonesia yang beberapa tahun belakangan ini cukup mengalami perkembangan yang signifikan. Sehingga tidak sedikit bank konvensional yang membuka divisi syariah guna berebut nasabah yang kian meminati sistem perbankan syariah. Kajian Jurnal Dialog edisi ini diawali dengan tulisan Dr. Euis Amalia yang mengulas tentang Perbankan Syariah di Indonesia: Kontribusinya Bagi Perekonomian Nasional dan Peran Perguruan Tinggi dalam Rangka Akselerasi. Dilanjutkan dengan tulisan Muhammad Taufiki, M.Ag yang mengupas tentang Aplikasi Konsep Hilah dalam Pengembangan Produk Perbankan Syariah (Analisa terhadap Fatwa tentang Syariah Charge Card).

M. Adlin Sila, MA, peneliti di Badan Litbang dan Diklat Depag mencoba mengulas kemungkinan Bank Syariah Sebagai Bank Bagi Hasil? Ah. Azharuddin Lathif, M.Ag, MH, Dosen Fakultas Syariah dan Hukum UIN Jakarta menghadirkan tulisan tentang Analisis Yuridis Pengenaan Pajak Pertambahan Nilai (Ppn) Dalam Pembiayaan Murabahah di Perbankan Syariah. Sedangkan Prof. Dr. Abd. Rachman Mas'ud Kepala Puslitbang Kehidupan Keagamaan, melalui tulisannya mencoba menyoroti Etika Professional dan Ruh Agama di Awal Millenium. Yulizar D. Sanrego \& Aam S. Rusydiana dosen di Tazkia Institute 
menghadirkan tulisan tentang Peran Perbankan Syariah dalam Mendukung Umkm Pertanian. Kajian ini dilengkapi dengan tulisan Iyoh Masthiyah Peneliti Puslitbang Pendidikan Agama dan Keagamaan Badan Litbang dan Diklat Depag tentang Hak Milik dalam Islam Perspektif Ibn Taymiyah. Kajian dalam Jurnal Dialog edisi ini kian lengkap dengan hadirnya tulisan Yulianti Muhammad yang menganalisis Prospek Perbankan Syariah di Indonesia.

Di samping memuat artikel ilmiah, Jurnal Dialog edisi ini juga memuat laporan hasil penelitian oleh
Dr. Anwar Abbas tentang Ekonomi Islam dan Pemberdayaan Ekonomi Rakyat; Studi Kasus Pemberdayaan Melalui Koperasi Pondok Pesantren Sidogiri Kab. Pasuruan Jawa Timur. Kajian ini diakhiri dengan telaah buku yang mengulas buku karya Drs. Cik Basir, SH, MHI, 2009. Penyelesaian Sengketa Perbankan Syariah di Pengadilan Agama dan Mahkamah Syar'iyah. Semoga kajian yang dihadirkan Jurnal Dialog edisi ini memberikan manfaat yang berarti bagi para pembaca, khususnya dalam kajian Perbankan Syariah di Indonesia. Selamat Membaca!

Redaksi 


\section{DIPTIRISI}

\section{TOPIK}

PERBANKAN SYARIAH DI INDONESIA:

Kontribusinya Bagi Perekonomian Nasional dan

Peran Perguruan Tinggi dalam Rangka Akselerasi

Euis Amalia -6

APLIKASI KONSEP HILAH

DALAM PENGEMBANGAN PRODUK PERBANKAN SYARIAH

(Analisa terhadap Fatwa tentang Syariah Charge Card)

H. Muhammad Taufiki -20

BANK SYARIAH SEBAGAI BANK BAGI HASIL: MUNGKINKAH?

M. Adlin Sila -30

ANALISIS YURIDIS PENGENAAN

PAJAK PERTAMBAHAN NILAI (PPN)

DALAM PEMBIAYAAN

MURABAHAH DI PERBANKAN SYARIAH

Ah. Azharuddin Lathif -52

ETIKA PROFESSIONAL DAN RUH AGAMA

DI AWAL MILLENIUM

Abd. Rachman Mas'ud -69

PERAN PERBANKAN SYARIAH DALAM

MENDUKUNG UMKM PERTANIAN

Yulizar D. Sanrego \& Aam S. Rusydiana -74

HAK MILIK DALAM ISLAM PERSPEKTIF IBN TAYMIYAH

Iyoh Masthiyah --90

PROSPEK PERBANKAN SYARIAH

DI INDONESIA: CERAH ATAU BURAM?

Yulianti Muhammad --101

\section{PENELITIAN}

EKONOMI ISLAM DAN

PEMBERDAYAAN EKONOMI RAKYAT; Studi Kasus Pemberdayaan Melalui

Koperasi Pondok Pesantren Sidogiri Kab. Pasuruan Jawa Timur

Anwar Abbas -117

\section{BOOK REVIEW}

PENYELESAIAN SENGKETA PERBANKAN SYARIAH

(Di Pengadilan Agama dan Mahkamah Syariah)

R. Meilani Dewi - 132 


\title{
EKonomi Islam dan PemberdayaAn EKONOMI RAKYAT
}

Studi Kasus Pemberdayaan Melalui Koperasi Pondok Pesantren Sidogiri

\author{
Kab. Pasuruan Jawa Timur
}

OLEH: ANWAR ABBAS*

\begin{abstract}
:
Islam has made an effort to balance between policy-oriented intervention and non-policyoriented intervention on economy. As a religion, Islam does not oppose the market's view of economy (liberal economics) nor the state's control over the economy. Rather, Islam tries to make the balance equally according to the level and the measurement between the two. In principle, Islam recognizes the concept of altruism that gives precedence to the willingness to work cooperatively. In Indonesia, this principle lies in the existence of cooperatives (koperasi). This article argues that the system of cooperatives has its root in Islamic principles called atta'âwun, meaning cooperation and togertherness. By taking Koperasi Pondok Pesantren Sidogiri Pasuran as its case study, this article found that koperasi managed to enhance the level of economic betterment of its members.
\end{abstract}

Di tengah krisis keuangan global yang melanda hampir semua negara, terutama negara-negara maju, para pengambil kebijakan (decision maker) bidang ekonomi di negara-negara yang dilanda krisis keuangan berupaya

* Lahir di Balaimnsiro Sumbar pada 15 Februari 1955. Menyelesaikan pendidikan Doktor Syariah di Universitas Islam Negeri Syarif Hidayatullah Jakarta tahun 2008. Strata Dua Magister Agama konsentrasi Ekonomi Islam di Universitas Muhammadiyah Jakarta dan sekaligus Magister Manajemen konsentrasi Marketing.; Dosen Universitas Islam Negeri Syarif Hidayatullah Jakarta; Ketua Majelis Ekonomi dan Kewirausahaan PP Muhammadiyah. optimal mencari jalan keluar. Satu jalan keluar yang telah disepakati bersama, yakni perlunya injeksi stimulus dari pihak pemerintah ke pasar, baik dalam bentuk stimulus fiskal, moneter, subsidi, dan stimulus yang mampu menggerakkan secara kontinyu roda perekonomian global. Itu artinya, pemerintah diundang kembali untuk melakukan campur tangan (intervention) ekonomi ke dalam pasar. Dalam konteks itulah, publik kembali ramai membicangkan kegagalan mekanisme pasar (market mechanism failure) untuk meluruskan pasar agar mencapai titik keseimbangan kembali (re-equilibrium). 
Dalam ihwal kegagalan pasar, intervensi pemerintah merupakan keharusan (sine qua none). Namun, intervensi yang perlu dilakukan harus terukur, sistematis, dan terancang sehingga tidak menimbulkan komplikasi distortif di kemudian hari. Artinya, perlu neraca kebijakan yang mampu menyeimbangkan kebijakan tentang kapan pemerintah melakukan intevensi, dan kapan pemerintah melakukan pelepasan intervensi ke pasar. Satu hal yang patut disepakati yakni, intervensi perlu dilakukan tatkala diperlukan pemihakan terhadap segmentasi atau sektor ekonomi yang menyangkut hajat hidup orang banyak.

Dalam kaitan inilah, ekonomi Islam berupaya menghitung neraca kebijakan intervensi dan kebijakan nonintervensi. Sebagai agama penyeimbang, Islam tidak antipasar dan tidak antipemerintah. Tapi, yang diperlukan adalah kadar dan ukuran kepemihakan. Dan itu artinya, menyangkut kehidupan ekonomi rakyat atau menyangkut hajat hidup orang banyak, pemerintah tidak boleh melepaskan dirinya untuk melakukan regulasi dan dalam penyediaan fasilitas untuk rakyat.

\section{FungSIONALISASI EKONOMI IsLAM}

Islam adalah agama yang memiliki khasanah konseptual untuk dikembangkan dalam kehidupan nyata. Untuk mengoperasionalisasikan ajaran, diperlukan Islam secara fungsional. Sebagaimana diketahui, Islam adalah agama yang diturunkan oleh Allah SWT untuk manusia melalui perantaraan utusannya, yaitu Nabi Muhammad SAW. Sumber-sumber agama Islam terdapat dalam Al Qur'an

118 Dialog No. 67 Tahun XXXII, Juli 2009 dan As Sunnah. Tujuan utama diturunkannya Al Qur'an tiada lain adalah agar dijadikan sebagai petunjuk fungsional bagi kehidupan manusia di muka bumi ini. Hal itu telah disampaikan Allah SWT, yaitu: "(Beberapa hari yang ditentukan itu ialah) bulan Ramadhan, bulan yang di dalamnya diturunkan (permulaan) Al Qur'an sebagai petunjuk bagi manusia dan penjelasanpenjelasan mengenai petunjuk itu dan pembeda (antara yang hak dan yang batil)". ${ }^{1}$

Petunjuk yang diberikan Allah dalam Al Qur'an adalah petunjuk yang lengkap dan sempurna. Semua masalah kehidupan yang akan dihadapi manusia telah ada penjelasan dan solusi fungsionalnya dalam Al Qur'an maupun As Sunnah. Hal itu telah dinyatakan oleh Allah SWT melalui firman-Nya: "Dan Kami turunkan kepadamu Al Kitab (Al Qur'an) untuk menjelaskan segala sesuatu dan petunjuk serta rahmat dan kabar gembira bagi orangorang yang berserah diri". ${ }^{2}$

Dengan demikian, di dalam Al Qur'an dan As Sunnah tentu akan didapati berbagai macam petunjuk Allah SWT yang dapat diambil oleh manusia untuk menyelesaikan segenap masalahmasalah dalam kehidupannya. Termasuk di dalamnya adalah masalahmasalah ekonomi. Dalam konteks itulah, diperlukan perumusan ajaran Islam dalam domain Islam fungsional bidang ekonomi.

Jika kita mau menggali kembali kepada sumber-sumber Al Qur'an dan As Sunnah, tiga pertanyaan yang mendasar di atas akan dapat di jawab satu per satu. Terhadap pertanyaan yang pertama, yaitu: sesungguhnya

\footnotetext{
${ }^{1}$ QS. Al Baqarah ayat 185

${ }^{2}$ QS. An-Nahl ayat 89)
} 
seluruh harta kekayaan yang ada di dunia itu hak milik siapa? Islam mempunyai sebuah pandangan yang berbeda sama sekali dengan dua sistem ekonomi yang ada. Islam memandang bahwa seluruh harta yang ada di dunia ini (bahkan seluruh alam semesta ini) sesungguhnya adalah milik Allah, berdasarkan firman Allah: "Dan berikanlah kepada mereka sebagian dari harta Allah yang dikaruniakannya kepadamu". ${ }^{3}$

Dari ayat ini dipahami bahwa harta yang dikaruniakan Allah kepada manusia sesungguhnya merupakan pemberian Allah yang dikuasakan kepadanya. Hal itu dipertegas dengan mendasarkan pada firman Allah: "Dan nafkahkanlah sebagian dari hartamu yang Allah telah menjadikan kamu menguasainya". ${ }^{4}$

Penguasaan (istikhlaf) ini berlaku umum bagi semua manusia. Semua manusia mempunyai hak pemilikan, tetapi bukan pemilikan yang sebenarnya. Oleh karena itu bagi individu yang ingin memiliki harta tertentu, maka Islam telah menjelaskan sebab-sebab pemilikan yang boleh (halal) dan yang tidak boleh (haram) melalui salah satu sebab pemilikan. Islam telah menggariskan hukumhukum perolehan individu, seperti: hukum bekerja, berburu, menghidupkan tanah yang mati, warisan, hibbah, wasiat dsb.

Ternyata sistem ekonomi Islam memandang bahwa harta kekayaan yang ada di dunia ini tidak hanya diperuntukkan pada individu untuk dapat dimiliki sepenuhnya, tetapi dalam Islam dikenal dan diatur pula tentang kepemilikan umum, yaitu pemilikan

${ }^{3}$ Q.S. An-Nuur Ayat 33

${ }^{4}$ Q.S. Al-Hadiid: 7 yang berlaku secara bersama bagi semua umat. Hal itu didasarkan pada beberapa Hadis Nabi, diantaranya adalah hadis Imam Ahmad Bin Hanbal yang diriwayatkan dari salah seorang Muhajirin, bahwasannya Rasulullah SAW telah bersabda: "Manusia itu berserikat dalam tiga perkara: air, rumput dan api"

Selain pemilikan umum, sistem ekonomi Islam juga mengatur tentang kepemilikan negara, seperti: setiap Muslim yang mati, sedang dia tidak memiliki ahli waris, hartanya bagi Baitul Mal, milik negara. Demikian juga contoh yang lain adalah adanya ketentuan tentang kharaj, jizyah, ghanimah, fa'i dan lainnya. Apabila harta itu telah dikuasai (dimiliki) oleh manusia secara sah, hukum Islam tidak membiarkan manusia secara bebas memanfaatkan harta tersebut. Islam telah menjelaskan dan mengatur tentang fungsi-fungsi pemanfaatan harta yang dibolehkan (halal) dan yang dilarang (haram). Islam mengharamkan pemanfaatan harta untuk membeli minuman keras, daging babi, menyuap, menyogok, berfoya-foya, dan sebagainya.

Selanjutnya Islam juga mengatur dan menjelaskan tentang pengembangan harta. Islam mengharamkan pengembangan harta dengan jalan menipu, membungakan (riba) dalam hal pinjam-meminjam maupun tukar-menukar, berjudi dsb. Islam membolehkan pengembangan harta dengan jalan jual beli, sewamenyewa, syirkah, musaqot dsb.

Adapun ketentuan Islam terhadap negara, maka Islam telah menjelaskan bahwa negara mempunyai tugas dan kewajiban untuk melayani

Dialog No. 67 Tahun XXXII, Juli 2009119 
kepentingan umat. Hal itu didasarkan pada salah satu hadits Imam Bukhari yang diriwayatkan dari Ibnu Umar yang mengatakan, Nabi SAW bersabda: "Imam adalah (laksana) penggembala (pelayan). Dan dia akan dimintai pertanggungjawaban terhadap urusan rakyatnya".

Agar negara dapat melaksanakan kewajibannya, Islam telah memberi kekuasaan kepada negara untuk mengelola harta kepemilikan umum dan negara dan tidak mengizinkan bagi seorangpun (individu maupun swasta) untuk mengambil dan memanfaatkannya secara liar. Kepemilikan umum seperti: minyak, tambang besi, emas, perak, tembaga, hutan harus dieksplorasi dan dikembangkan dalam rangka mewujudkan kemajuan taraf ekonomi rakyat.

Distribusi kekayaan itu diserahkan sepenuhnya kepada kewenangan Imam (pemimpin negara) dengan melihat dari mana sumber pemasukannya (misalnya, harus dibedakan antara: zakat, jizyah, kharaj, pemilikan umum, ghanimah, fa'i dsb), maka Islam telah memberikan ketentuan pengalokasiannya kepada pihak-pihak yang berhak menerimanya. Prinsip umum pendistribusian oleh negara, didasarkan pada firman Allah: "Supaya harta itu jangan hanya beredar di antara orang-orang kaya saja di antara kamu". ${ }^{5}$

Maksud dari ayat di atas adalah agar peredaran harta tidak hanya terbatas pada orang-orang kaya saja di negara tersebut. Oleh karena itu, menurut Islam harta itu seharusnya hanya bisa dimiliki, dimanfaatkan,

${ }^{5}$ Q.S. Al Hasyr ayat 7

120 Dialog No. 67 Tahun XXXII, Juli 2009 dikembangkan dan didistribusikan secara sah apabila sesuai dengan izin dari Allah sebagai Dzat pemilik hakiki dari harta tersebut.

Secara lebih terperinci dapat disimpulkan bahwa Sistem Ekonomi Islam menurut An Nabhani dalam Mubyarto $(2002)^{6}$, yakni: pertama, kepemilikan (al-milkiyah), yang meliputi: Kepemilikan individu (almilkiyah al-fardiyah). Kepemilikan umum (al milkiyah al-'ammah). Kepemilikan negara (al milkiyah addaulah).Kedua, Pemanfaatan kepemilikan (al-tasharruf fi al-milkiyah), yang meliputi: penggunaan harta (infaq almaal), yaitu untuk konsumsi. Pengembangan kepemilikan (tanmiyat al milkiyah), yaitu untuk produksi. Ketiga, distribusi harta kekayaan di tengahtengah manusia (tauzi'u tsarwah bayna Al-Naas), yang meliputi: Distribusi secara ekonomis, melalui peran individu.

Kita tentu tidak terlalu kaget jika ada 3 orang terkaya di dunia ini, ternyata kekayaannya lebih besar dari gross domestic product (GDP) 48 negara termiskin dunia. Itu berarti setara dengan seperempat jumlah total negara di dunia. Itu adalah hasil penelitian Brecher dan Smith. Demikian juga, tidak kalah hebatnya, menurut penelitian Noam Chomsky, 1\%

\footnotetext{
${ }^{6}$ Sistem ekonomi Islam, memiliki perbedaan yang sangat mendasar dengan sistem ekonomi yang lain, baik kapitalisme maupun sosialisme. Sistem ekonomi Islam tidak membiarkan harta kekayaan yang ada di bumi ini "diperebutkan" secara bebas sebagaimana dalam ekonomi kapitalisme. Akibat dari persaingan bebas dalam ekonomi kapitalisme, sebagaimana telah umum difahami telah mengakibatkan pihak yang kaya semakin kaya, sedangkan yang miskin semakin miskin.
} 
penduduk dengan pendapatan tertinggi dunia, setara dengan $60 \%$ penduduk pendapatan terendah dunia, yaitu sama dengan pendapatan dari 3 milyar manusia. Itulah "karya" nyata dari ekonomi kapitalisme. ${ }^{7}$

Demikian juga, sistem ekonomi Islam juga dapat dibedakan dengan dengan jelas terhadap sistem ekonomi sosialisme. Hal itu disebabkan, di dalam sistem ekonomi Islam tetap memberi ijin kepada individu-individu untuk memiliki harta kekayaan, sebanyak apapun, sepanjang harta itu diperoleh melalui jalan yang dihalalkan oleh Islam. Jika kepemilikan individu tidak diakui, maka akibatnya dapat dilihat pada sistem ekonomi sosialisme, yaitu menyebabkan gairah kerja dan semangat berproduksi menjadi hilang.

Keunggulan dari sistem ekonomi Islam terutama dapat dilihat dari adanya kepemilikan umum. Sumber-sumber daya alam yang besar seperti hutan, tambang, minyak, gas, batubara, listrik, air dsb. adalah termasuk dalam kategori kepemilikan umum, sehingga seluruh hasil dari sumber daya alam tersebut harus dikembalikan kepada rakyat sebagai pemilik hakiki dari harta tersebut. Harta tersebut bukanlah milik negara, bukan milik individu, bukan milik swasta, apalagi milik swata asing sebagaimana fakta terjadinya "perampokan" dan "penjarahan" yang saat ini banyak dilakukan oleh perusahaan-perusahaan asing dari negara maju kepada negara berkembang. ${ }^{8}$

7 Triono, Dwi Condro. Bahaya Ekonomi NeoLiberal di Indonesia. Media Politik dan Dakwah Al Wai'e. No. 57. Tahun V. Mei 2005.

8 Perkins, John, 2006. Confessions of an Economic Hit Man.

\section{Membaca Ekonomi Rakyat}

Dari gambaran tentang ekonomi Islam yang dipaparkan di atas, menjadi jelas bahwa ekonomi Islam mempertegas posisinya, yang tidak saja berada dalam domain kebijakan intervensi dan nonintervensi, tapi ekonomi Islam mengarahkan pada kadar kebijakan. Tapi, yang pasti, ekonomi Islam melakukan pemihakan terhadap segmen ekonomi yang dieksploitasi oleh sistem sosial yang membuat segmen ekonomi tersebut menjadi miskin, teraniaya, dan kehilangan akses (kesempatan). Dalam posisi itu, ekonomi Islam secara terang benderang melakukan pemihakan terhadap ekonomi kerakyatan, yang selama ini terpinggirkan posisinya dalam rotasi penguasaan oleh ekonomi berskala besar.

Muhammad Hatta dalam tulisannya yang dimuat dalam majalah Daulat Rakjat no. 84 tanggal 10 Januari 1934 menulis bahwa "ekonomi rakyat Indonesia yaitu unit-unit ekonomi serba kecil termasuk pemberi jasa dalam proses produksi, yaitu kaum buruh, terus berada dalam posisi antara hidup dengan mati" ${ }^{9}$. Sementara itu Sri Edi Swasono mendefinisikan bahwa "ekonomi rakyat adalah kegiatan ekonomi riil yang tiap hari menghidupi rakyat bawah. ${ }^{10}$

\footnotetext{
9 Sritua Arif, 2002, Pembangunisasi dan Ekonomi Indonesia: Pemberdayaan Rakyat dalam Arus Globaliasi, Pustaka Zaman, Jakarta. hlm, 81

${ }^{10}$ Sri-Edi Swasono, Indonesia is Not for Sale : Sistem Ekonomi Nasional Untuk Sebesar-besar Kemakmuran Rakyat, Demokrasi Ekonomi- Ekonomi Kelembagaan (Jakarta: Badan Perencanaan Pembangunan Nasional, 2007).
}

Dialog No. 67 Tahun XXXII, Juli 2009121 
Sementara ekonomi kerakyatan merupakan sebuah sistem perekonomian yang memihak pada ekonomi rakyat" Kemudian Adi Sasono memaparkan bahwa demokrasi ekonomi dalam Pasal 33 UUD 1945 oleh para pendiri Republik Indonesia sebenarnya menggunakan istilah ekonomi rakyat sebagai ekonomi rakyat Indonesia kebanyakan. Adapun ekonomi kerakyatan merupakan ungkapan lain dari sistem ekonomi dalam konteks Indonesia termaktub dalam kata demokrasi ekonomi. Demokrasi ekonomi, sebagaimana amanat konstitusi, menghendaki adanya "keadilan" dan "pemerataan" dalam penguasaan aset dan sumber daya ekonomi nasional antar pelaku ekonomi ${ }^{11}$.

Defenisi lain adalah seperti yang diungkapkan Salim Siagian bahwa ekonomi rakyat adalah kegiatan ekonomi rakyat banyak di suatu negara atau daerah yang pada umumnya tertinggal bila dibandingkan dengan perekonomian negara atau daerah bersangkutan secara rata-rata. ${ }^{12}$ Sedangkan Zulkarnain mendefenisikan "ekonomi kerakyatan (perekonomian rakyat) adalah ekonomi pribumi (people's economy is indegeneous economy), bukan aktivitas perekonomian yang berasal dari luar aktivitas masyarakat (external economy). Yang dimaksud dengan ekonomi rakyat adalah perekonomian atau perkembangan ekonomi masyarakat yang berkembang

11 Adi Sasono, 1999, Pemberdayaan Ekonomi Rakyat Menuju Indonesian Baru, Cidesindo, Jakarta. Hlm 321.

${ }^{12}$ Salim Siagian dalam Majalah Usahawan no 02 Th XXX Februari 2001 relatif lambat, sesuai dengan kondisi yang melekat pada kelompok masyarakat tersebut"13

Jadi, ekonomi rakyat adalah sektor kegiatan perekonomian masyarakat bawah atau masyarakat yang termarjinalkan, sementara ekonomi kerakyatan berkaitan dengan sistem kebijakan dalam bidang perekonomian. Sebenarnya istilah ekonomi kerakyatan ini dipopulerkan kembali untuk mengganti istilah ekonomi rakyat yang tidak disukai oleh sebagian kalangan, maka berhasillah konsep itu masuk TAP MPR yaitu TAP Ekonomi Kerakyatan No. XVI/1998. Dan istilah ekonomi kerakyatan ini kemudian semakin dimantapkan dalam banyak TAP-TAP MPR berikutnya termasuk kemudian UU No. 25 tahun 2000 tentang Propenas. Bahwa konsep Ekonomi Kerakyatan ini merupakan konsep politik yang "dipaksakan" nampak kemudian dari penggunaannya yang simpang siur. Karena definisi konkret yang dianut pemerintah ternyata belum begitu jelas. ${ }^{14}$

Dalam tingkat wacana sebenarnya yang lebih populer adalah istilah ekonomi rakyat. Ekonomi rakyat adalah kegiatan atau mereka yang berkecimpung dalam kegiatan produksi untuk memperoleh pendapatan bagi kehidupannya. Mereka itu adalah petani kecil, nelayan, peternak, pekebun, pengrajin, pedagang kecil dan lain-lain, yang modal usahanya merupakan modal keluarga (yang kecil), dan pada

13 Zulkarnain, 2003, Membangun Ekonomi Rakyat: Persefsi Tentang Pemberdayaan Ekonomi Rakyat, Adicipta, Yogyakarta., hlm. 34

14 UU No. 25 Tahun 2000 tentang Program Pembangunan Nasional (Propenas) 
umumnya tidak menggunakan tenaga kerja dari luar keluarga. Tekanan dalam hal ini adalah pada kegiatan produksi, bukan konsumsi, sehingga buruh pabrik tidak masuk dalam profesi atau kegiatan ekonomi rakyat, karena buruh adalah bagian dari unit produksi yang lebih luas yaitu pabrik atau perusahaan. Demikian meskipun sebagian yang dikenal sebagai UKM (Usaha KecilMenengah) dapat dimasukkan ekonomi rakyat, namun sebagian besar kegiatan ekonomi rakyat tidak dapat disebut sebagai "usaha" atau "perusahaan" (firm) seperti yang dikenal dalam ilmu ekonomi perusahaan. ${ }^{15}$

\section{Ekonomi Kerakyatan Sebagai Sebuah SISTEM}

Sistem ekonomi kerakyatan adalah sistem ekonomi yang mengikut sertakan seluruh lapisan masyarakat ke dalam proses pembangunan. ${ }^{16}$ Cakupan sistem ini adalah keseluruhan dari administrasi pembangunan perekonomian nasional, yang dimulai dari perencanaan, pengorganisasi, penggerakan, pengawasan, bahkan sampai tingkat pelaporan dan audit publik.

Sri Edi Swasono dalam pengukuhannnya sebagai guru besar Fakultas Ekonomi Universitas Indonesia mengemukakan, "Sistem ekonomi Indonesia yang berdasarkan atas dasar Demokrasi Ekonomi itu akan lebih cepat terwujud jika dalam setiap penyusunan kebijakasanaan dikaitkan lebih langsung dengan butir-butur

15 Revrisond Baswir (1999) dalam Drama Ekonomi Indonesia: Belajar Dari Kegagalan Orde Baru: 2004. Penerbit: Kreasi Wacana, Yogyakarta, hlm, 76

${ }^{16}$ Op. cit. Zulkarnain, 2003., hlm. 76 demokrasi ekonomi. Dengan demikian perencanaan pembangunan sekaligus perencanaan sistem, dan pembangunan ekonomi sekaligus merupakan pembangunan sistemnya". ${ }^{17}$ Pandangan yang dikemukakan Sri Edi Swasono ini tentunya tidaklah berlebihan, sebab sebagai sebuah negara yang berdaulat, maka aturan main dalam kegiatan berekonomi merupakan bagian yang sangat penting, terutama menyangkut nilainilai idiologi, budaya, tatanan sosoial dan sebagainya. Dan tatanan ini hendaklah menyentuh ke sebagian besar rakyat jika tidak bisa kepada seluruh rakyat bangsa Indonesia.

Sebagai sebuah bentuk kegiatan ekonomi yang lebih bertumpu kepada usaha-usaha bersekala kecil dan menengah, sesungguhnya ekonomi kerakyatan telah mendapatkan kepastian hukum dalam sistem kenegaraan Indonesia. Hal ini dapat lihat dalam beberapa pasal pada UUD 1945 yang menyangkut bidang perekonomian, baik setelah maupun sebelum diadakannya amandemen.

Sebelum diadakannya amandemen, pasal 33 UUD 1945, mengatur sedemikianrupa tentang bagaimana seharusnya kegiatan perekonomian dijalankan, terutama pada ayat satu yang menyatakan perekonomian disusun sebagai usaha bersama berdasar atas asas kekeluargaan. Begitupun pada pasal dua dan tiga, dimana negara secara dominan mengatur semua potensi alam dan kekayaan alam yang diperuntukan sebesar-besarnya bagi kemakmuran rakyat, bahkan pada penjelasan UUD

17 Mubyarto dalam Membangun Sistem Ekonomi, BPFE, Yogyakarta., hlm. 241

Dialog No. 67 Tahun XXXII, Juli 2009123 
1945 memberikan gerak yang sangat besar bagi pengembangan ekonomi kerakyatan melalui koperasi. Selain itu hal lain yang juga mendasar terletak pada "demokrasi ekonomi" sebagai dasar pelaksanaan pembangunan yang memiliki ciri-ciri positif sebagai berikut:

1. Perekonomian disusun sebagai usaha bersama berdasarkan atas asas kekeluargaan

2. Cabang-cabang produksi yang penting bagi negara dan menguasai hajat hidup orang banyak dikuasai oleh negara.

3. Bumi dan air dan kekayaan alam yang terkandung di dalamnya dikuasai oleh negara dan dipergunakan untuk sebesarbesarnya kemakmuran rakyat.

4. Sumber-sumber kekayaan dan keuangan Negara digunakan dengan permufakatan LembagaLembaga Perwakiolan Rakyat, serta pengawasan terhadap kebijakannya ada pada Lembaga Perwakilan Rakyat pula.

5. Warga negara memiliki kebebasan dalam memilih pekerjaan yang dikehendaki serta mempunyai hak dan pekerjaan yang layak.

6. Hak milik perorangan diakui dan pemanfaaatannya tidak boleh bertentangan dengan kepentingan masyarakat.

7. Potensi, inisiatif dan daya kreasi setiap warga negara diperkembangkan sepenuhnya dalam batas-batas yang tidak merugikan kepentingan umum.

Ketujuh pointer sebagaimana yang dikemukakan di atas, jelas menunjukan sesungguhnya perekonomian Indonesia menganut kepada sebuah perekonomian yang berpihak kepada rakyat yang lazim sebut sebagai ekonomi kerakyatan.

Keberpihakan terhadap sisitem ini sesungguhnya semakin jelas setelah diadakannya amandemen terhadap UUD 1945 dimana beberapa pasal secara tegas dan mendetil menjelaskan tentang perekonomian negara yang berpihak kepada ekonomi rakyat. Salahsatu pasal yang mengatur tentang ini diantaranya adalah sebagaimana yang diungkapkan dalam pasal 35 UUD 1945 yang menyatakan :perekonomian nasional diselenggarakan berdasar atas demokrasi ekonomi dengan prinsif kebersamaan, efisiensi berkeadilan, berkelanjutan, berwawasan lingkungan, kemandirian, serta dengan menjaga keseimbangan kemajuan dan kesatuan ekonoimi nasional. ${ }^{18}$.

\section{Koperasi: Muara EKonomi Islam dan EKONOMI RAKYAT}

Salah satu instrumen penting dari muara antara ekonomi Islam dan ekonomi rakyat yang telah dijelaskan di atas adalah keberadaan koperasi. Kendati konsep koperasi secara modern berasal dari konsep Barat, tapi dalam realitasnya praktik-praktik koperasi sesungguhnya sudah hidup dan berakar lama di Tanah Air. Demikian pula dalam konsep Islam dikenal adanya usaha bersama (at-ta'âwun) yang didasarkan atas asas kekeluargaan. Konsep dalam Islam itu dalam bahasa modernnya disebut koperasi (atta'âwun). Secara eksplisit, seperti yang diuraikan pada awal bahasan di atas, bahwa dalam Hadits Nabi, terutama dalam hadits Imam Ahmad Bin Hanbali yang diriwayatkan dari salah seorang

\footnotetext{
${ }^{18}$ Tap MPR RI Tahun 2003
} 
Muhajirin, bahwasannya Rasulullah SAW telah bersabda: "Manusia itu berserikat dalam tiga perkara: air, rumput dan api".

Semakin jelas, bahwa salah satu titik temu antara konsep ekonomi Islam dan konsep ekonomi rakyat adalah koperasi. Sebagaimana yang dijelaskan dalam pasal 1 ayat 1 UU no 25 tahun 1992 "koperasi adalah badan usaha yang beranggotakan orang-orang atau badan hukum Koperasi dengan melandaskan kegiatannyanya berdasarkan pronsip Koperasi sekaligus sebagai gerakan ekonomi rakyat yang berdasarkan atas asa kekeluargaan". ${ }^{19}$ Dari defenisi tersebut menunjukan empat hal penting yang menyangkut sebuah sistem perekonomian, yaitu:

1. Koperasi merupakan badan hukum: Ini menunjukan bahwasanya dengan menggunakan koperasi sebagai wadah usaha, akan memiliki sebuah kekuatan hukum guna kelangsungan usaha, terutama dalam aspek legalitas usaha baik dalam mendapatkan tambahan modal, kepastian sistem dan lain sebagainya.

2. Koperasi berdasarkan prinsip: Ini menunjukan bahwasanya ada koridor yang diatur secara tegas tentang bagaimana seharusnya koperasi digerakan, baik tentang keanggotaanya, pengelolaan, pembagian keuntungan, balas jasa, maupun kemandirian usaha.

3. Koperasi sebuah gerakan ekonomi rakyat: Ini menunjukkan bahwa koperasi adalah alat yang dapat digunakan membangun ekonomi

${ }^{19}$ Revrisond Baswir dalam Drama Ekonomi Indonesia: Belajar Dari Kegagalan Orde Baru: 2004. Penerbit: Kreasi Wacana, Yogyakarta, hlm 264. rakyat sebagai sebuah kekuatan moral ekonomi guna memajukan kesejahteraan masyarakat yang tidak hanya kelompok atau individu tertentu saja.

4. Koperasi berasaskan kekeluargaan: Ini menunjukan bahwasanya dengan koperasi para anggotanya senantiasa bekerjasama dalam berusaha, bersatu padu dan menumbuhkan sikap tolong menolong.

Bung Hatta sendiri sebagai peletak dasar konsep koperasi di Tanah Air sekaligus digelar Bapak Koperasi, menjelaskan bahwa dalam pasal 33 UUD 1945 yang dirumuskannya dijelaskan bahwa "perekonomian disusun sebagai usaha bersama berdasar atas asas kekeluargaan."

Ini menunjukkan bahwa perekonomian Indonesia harus disusun sebagai usaha bersama (at-ta'âwun) berdasarkan atas asas kekeluargaan dan atau kerjasama. Oleh karena itu di dalam diri masing-masing pelaku ekonomi yang ada, baik berupa perusahaan negara, koperasi dan perusahaan swasta, harus ada semangat kebersamaan dan kekeluargaan serta kerjasama tanpa itu maka tujuan dan cita-cita pembangunan tidak akan dapat tercapai..

Mengenai betapa pentingnya masalah kerjasama ini, hal serupa juga telah dikemukakan oleh Ibnu Khaldun. Khaldun mengatakan bahwa: "kebutuhan manusia sangat banyak, untuk itu diperlukan usaha yang banyak juga adalah diluar kemampuan manusia untuk melakukan semua itu ataupun sebagiannya, kalau hanya sendirian saja. Jelaslah bahwa ia tidak

Dialog No. 67 Tahun XXXII, Juli 2009125 
dapat berbuat banyak tanpa bergabung dengan beberapa tenaga lain dari sesama manusia, jika ia hendak memperoleh makanan bagi dirinya dan sesamanya. Dengan bergotong royong (ta'awun)maka kebutuhan manusia kendati beberapa kali lebih banyak dari jumlah mereka dapat dipenuhi." 20

Dari penjelasan di atas terlihat betapa penting dan strategisnya peran kerjasama dalam kehidupan ekonomi bagi terpenuhinya kebutuhan dan terciptanya kesejahteraan bagi seluruh ummat manusia. Bahkan mengingat pentingnya peran kerjasama tersebut dalam kehidupan ekononomi, terutama kehidupan ekonomi suatu negara, menurut Sri-Edi Swasono "tanpa adanya kemauan untuk memperhitungkan unsur dan mekanisme kerjasama , dan tanpa adanya kemauan bekerjasama (willingness to cooperate), teori pertumbuhan ekonomi akan cacat pada tataran empirik “21.

Oleh karena itu untuk suksesnya pembangunan sebuah perekonomian maka sebuah negara harus mampu menggelorakan kerjasama di antara para pelaku ekonominya sehingga terbentuklah sinergi yang mampu mendorong bagi terjadinya pertumbuhan dan pemerataan di kalangan pelaku ekonomi yang ada bagi terwujudnya kesejahteraan sosial bagi seluruh masyarakat.

Untuk itu segala sesuatu yang akan merusak nilai-nilai luhur tersebut haruslah dihindarkan. Di sinilah bisa

20 'Abd ar-Rahman ibn Khaldun, al Muqoddamah (TunisL al Daru al Tunisiyatu li al Nasyri), h. 77.

${ }^{21}$ Sri-Edi Swasono, Indonesia is Not for Sale : Sistem Ekonomi Nasional Untuk Sebesar-besar Kemakmuran Rakyat, Demokrasi Ekonomi- Ekonomi Kelembagaan (Jakarta: Badan Perencanaan Pembangunan Nasional, 2007), h. 30. dipahami mengapa bangsa Indonesia sangat menentang paham yang mendukung konsep free fight liberalism (pasar bebas) seperti yang diusung Adam Smith dan kawan-kawannya. Bung Hatta tidak percaya sistem ini akan dapat membawa "segala hubungan ekonomi secara otomatis ke jurusan persesuaian dan kepada keadaan setimbang "22 sebab di dalam kenyataan kehidupan sehari-hari impian tentang akan terbentuknya natural order dan natural price itu sulit sekali ditemukan. Karena persaingan dan pasar bebas yang bisa melahirkan kebaikan dan kemashlahattan itu memerlukan persyaratan. Di antara syarat-syarat yang diperlukannya menurut Hatta adalah "apabila subyeksubyek ekonomi itu kira-kira sama kuat kedudukannya, sama-sama cerdik dan sama-sama mempunyai kepandaian. itulah yang tidak ada dari semulanya" 23 sehingga akibat dari pasar bebas itu selanjutnya "yang lemah dihancurkan oleh yang kuat dengan sendirinya." ${ }^{24}$

Jadi, dalam pasar bebas yang terjadi tidak lagi kerjasama, tetapi adalah praktik yang mendorong dan menjurus kepada terjadinya praktik monopoli ${ }^{25}$.

\footnotetext{
${ }^{22}$ Mohammad Hatta, Ekonomi Terpimpin (Jakarta: Penerbit Mutiara, 1979), h. 15.

${ }^{23}$ Mohammad Hatta, Ekonomi Terpimpin (Jakarta: Penerbit Mutiara, 1979), h. 15

${ }^{24}$ Mohammad Hatta, Ekonomi Terpimpin (Jakarta: Penerbit Mutiara, 1979), h. 17.

${ }^{25}$ Sehingga dalam hal ini kata Hatta "bermulalah proses pergabungan menuju konsentrasi yang berupa trust, kartel dan konsern. Pergabungan itu diadakan secara horisontal dan vertikal. tujuannya terang yaitu untuk menguasai pasar dan sumber bahan. ... maka terjadilah yang aneh. kemerdekaan yang diberikan kepada subyek-subyek ekonomi di pasar dipergunakan mereka untuk menghilangkan kemerdekaan pasar. Apabila ini terjadi maka
} 
Oleh karena itu belajar dari kenyataan demikian, Bung Hatta dalam konsep ekonominya tidak berkeinginan mengusung pasar bebas tetapi bagaimana membangun dan mengembangkan ekonomi bangsa ini melalui sebuah usaha bersama dengan berdasar asas kekeluargaan agar segala potensi sumber daya yang ada dapat dimanfaatkan dengan sebaik-baiknya bagi kesejahteraan dan untuk sebesarbesar kemakmuran rakyat dan atau masyarakat.

Seperti apakah aplikasi bentuk kerjasama ekonomi yang diharapkan? Di antara bentuk kerjasama ekonomi yang sangat diharapkan bangsa Indonesia, yaitu kerjasama ekonomi dalam bentuk koperasi. Bahkan, karena begitu menonjolnya pikiran Bun Hatta tentang lembaga ekonomi yang satu ini, hampir-hampir masalah koperasi diidentikkan orang dengan Hatta. Hal ini dapat dipahami karena seperti dikatakan Deliar Noer "lembaga usaha yang mendapat tempat sentral dalam sistem ekonomi yang dikembangkan Hatta ialah koperasi." 26 Apalagi mengingat ide tentang koperasi seperti yang termuat dalam Pasal 33 UUD 1945 itu adalah banyak "dihubungkan dengan nama Bung Hatta." ${ }^{27}$ Karena memang beliaulah yang merumuskan dan menuangkannya ke dalam pasal

Pemerintah tidak dapat lagi tinggal diam dan terpaksa campur tangan untuk memberi perlindungan kepada yang lemah." . Lihat Mohammad Hatta, Ekonomi Terpimpin (Jakarta: Penerbit Mutiara, 1979), h. 18.

${ }^{26}$ Deliar Noer, Mohammad Hatta: Biografi Politik (Jakarta: LP3ES, cetakan kedua, 1991), h. 545-546.

${ }^{27}$ Dj.A.Simarmata, Reformasi Ekonomi, Menurut Undang-Undang Dasar 1945: Kajian Ringkas dan Interpretasi Teoritis (Jakarta: Lembaga penerbit Fakultas Ekonomi Universitas Indonesia, 1998), h.53. tersebut dan menjadikan koperasi sebagai lembaga strategis dan menjadi "senjata persekutuan bagi si lemah untuk mempertahankan hidupnya." 28

Tetapi, ini tidaklah berarti bahwa lembaga-lembaga usaha lainnya seperti lembaga yang diusahakan oleh pemerintah dan swasta tidak mendapat perhatian dari Hatta karena ketiga pelaku tersebut menurut Hatta adalah menjadi pilar dalam perekonomian Indonesia.

Namun yang perlu mendapat perhatian di sini, bahwa konsep dan kehadiran koperasi bagi Hatta bukanlah sesuatu yang di dasarkan kepada idealisme semata, tetapi juga merupakan tuntutan dari realitas keadaan ekonomi masyarakat waktu itu yang memerlukan kehadiran struktur perekonomian yang baru karena struktur perekonomian yang ada selama ini telah membawa kepada ketidakadilan dan tidak memihak kepada sebagian besar rakyat dan atau pribumi Menurut Hatta struktur perekonomian Indonesia di masa itu terdiri dari tiga golongan ekonomi yang tersusun bertingkat yaitu: “...golongan atas ialah perekonomian kulit putih terutama bangsa Belanda.... Lapis ekonomi kedua yang menjadi perantara dan hubungan dengan masyarakat Indonesia berada kira-kira $90 \%$ di tangan orang Cina dan orang Asia lainnya. Orang Indonesia yang dapat dimasukkan ke dalam lapis kedua ini paling banyak mengisi $10 \%$ dari lapis itu.... Lapis ketiga ialah perekonomian yang segala kecil;

${ }^{28}$ Mohammad Hatta, Beberapa Fasal Ekonomi: Djalan Ke Ekonomi dan Pembangunan (Djakarta, Dinas Penerbitan Balai Pustaka, Tjetakan keenam, 1960), h.120.

Dialog No. 67 Tahun XXXII, Juli 2009127 
pertanian kecil, pertukangan kecil, perdagangan kecil dan lain-lain, itulah daerah ekonomi bangsa Indonesia . Pun pekerja segala kecil, kuli, buruh kecil dan pegawai kecil diambil dari dalam masyarakat Indonesia ini." 29

Struktur perekonomian yang seperti ini adalah tidak sehat dan tidak menguntungkan bagi rakyat kecil yang tidak punya modal. Bahkan dia melihat "soesoenan ekonomi jang sematjam itulah jang membesarkan kesoesahan rakjat dan membelenggoe dia dalam keadaan tidak mampoe." 30 Padahal yang menjadi pelaku sebenarnya dalam kehidupan ekonomi tersebut adalah bangsa Indonesia, karena kaum produsen, sebagian besar terdiri dari bangsa Indonesia. Kaum konsumen demikian pula. Akan tetapi kaum distribusi terdiri dari pada bangsa asing dan kelompok Cina.

Mengapa hal ini terjadi? salah satu penyebab mengapa bangsa Indonesia tidak bisa memainkan peranan penting dalam hal ini adalah karena "penghasilan kita amat terpecahpecah," ${ }^{31}$ ekonomi kita, adalah ekonomi segala kecil.

Ini terlihat misalnya dalam bidang produksi. Di mana-mana terdapat produsen yang kecil-kecil. Mereka bekerja dengan hampir tidak punya modal. Dengan keadaan yang seperti ini, tentu saja, mereka mudah kena jerat si lintah darat dalam desanya, sehingga jadilah petani kita hanya menjadi

${ }^{29}$ Mohammad Hatta, Membangun Ekonomi Indonesia (Jakarta: Inti Idayu Press, 1985), h.81-82.

${ }^{30}$ Mohammad Hatta, Daulat Rakyat, Tahun ke III, No. 7920 November, tahun 1933, h. 201.

${ }^{31}$ Mohammad Hatta, Daulat Rakyat, Tahun ke III, No. 79, 20 November, tahun 1933, h. 202.

128 Dialog No. 67 Tahun XXXII, Juli 2009 tukang tanam, sedangkan buahnya sudah ada orang asing yang empunya.

Meminjam istilah Selo Sumardjan, para produsen semakin bertambah miskin bukan karena mereka malas bekerja atau karena sakit yang berkepanjangan, tetapi karena "struktur sosial masyarakat itu tidak dapat ikut menggunakan sumbersumber pendapatan yang sebenarnya tersedia bagi mereka" ${ }^{32}$ sehingga terciptalah di tengah-tengah masyarakat apa yang disebut dengan "kemiskinan struktural." 33

Begitu juga dalam kedudukan mereka sebagai konsumen, nasib bangsa Indonesia juga tak jauh berbeda. "Sebagai si pembeli nasibnja bergantung kepada kaoem saudagar bangsa asing. Dan mereka inilah poela jang menetapkan harga barang-barang jang perlu bagi rakjat. Dengan djalan pioetang mereka dapat pula mengikat si pembeli." ${ }^{34}$

Dengan demikian, secara umum, mengingat luhurnya maksud yang terkandung dalam konsep koperasi, dapat disimpulkan bahwa konsep tentang koperasi ini adalah sangat sesuai dan atau sejalan dengan ajaran Islam terutama seperti yang terdapat dalam Qs. al Maidah : 5:3 yang memang sangat mendorong akan adanya kerjasama (ta'âwun) dan atau tolong-menolong dalam kebaikan dan taqwa di dalam segala segi kehidupan termasuk dalam bidang ekonomi.

32 Alifan, dkk (penghimpun), Kemiskinan Struktural: Suatu Bunga Rampai (Jakarta: Yayasan Ilmu-Ilmu Sosial, cetakan I, 1980), h. 5.

33 Alifan, dkk (penghimpun), Kemiskinan Struktural: Suatu Bunga Rampai (Jakarta: Yayasan Ilmu-Ilmu Sosial, cetakan I, 1980), h. 5.

${ }_{34}$ Mohammad Hatta, Daulat Rakyat, Tahun ke III, No. 7920 November 1933, h. 250. 


\section{Kasus Koppontren: Basis Penguatan EKONOMI RAKYAT}

Setelah mengulas eksistensi Koperasi sebagai landasan ekonomi rakyat yang memiliki basis ideologis ajaran ekonomi Islam, menjadi jelas bahwa koperasi adalah inti gerakan pemberdayaan ekonomi rakyat. Peningkatan kesejahteraan ekonomi rakyat akan sulit berhasil jika koperasi tidak dikembangbiakkan secara serius, baik oleh pemerintah maupun masyarakat.

Oleh karena itu, pesantren sebagai basis pendidikan tradisional dan telah terbukti peran dan kontribusinya dalam pendidikan nasional, dalam beberapa tahun terakhir ini telah mengembangkan koperasi yang dikelola secara modern. Pondok pesantren, saat ini dipahami bukan hanya sebagai lembaga pendidikan keagamaan untuk mencetak generasi berprilaku islami, tetapi sekaligus mampu membuktikan diri sebagai lembaga perekonomian guna menyejahterakan santri serta masyarakat luas.

Langkah tersebut telah dibuktikan Pondok Pesantren Sidogiri Pasuruan. Ponpes yang didirikan oleh Sayyid Sulaiman pada 263 tahun silam di Desa Sidogiri, Kec. Kraton, Kabupaten Pasuruan, itu bahkan berhasil mengembangkan konsep ekonomi syariah.

Kiprah ponpes tersebut di bidang ekonomi diawali keinginan untuk mandiri/tanpa mengharapkan bantuan pihak lain, dengan mendirikan koperasi pada 1981. Usaha awal berupa kedai dan warung kelontong di dalam lingkungan pesantren memenuhi kebutuhan para santri.
Koperasi Ponpes Sidogiri (Koppontren Sidogiri) terus berkembang, dengan menerapkan konsep kerjasama ( $\left.t a^{\prime} a ̂ w u n\right)$ dan atau tolong-menolong dalam kebaikan dan taqwa dengan prinsip dari santri, oleh santri dan untuk santri. Artinya, modal koppontren dihimpun dari santri, dikelola oleh santri dan keuntungannya juga kembali ke santri.

Dalam perkembangannya, pengurus Koppontren Sidogiri dan beberapa guru Madrasah Miftahul Ulum Ponpes Sidogiri pada pertengahan 1997 menyelenggarakan kegiatan usaha dengan fokus simpan pinjam pola syariah bernama Baitul Mal wa Tamwil Maslahah Mursalal lil Ummah (BMT-MMU).

Usaha tersebut guna merespon keresahan masyarakat sekitar pesantren yang mulai terjerat praktik ekonomi ribawi dalam bentuk rentenir. BMTMMU mengalami kemajuan secara signifikan dari aspek permodalan, aset maupun omzetnya. Saat ini omzet bisnis syariah mencapai Rp42 miliar per tahun. Adapun jumlah nasabahnya mencapai 12.000 orang lebih. Uni layanannya pun berkembang menjadi 12 unit yang tersebat di berbagai kecamatan di Pasuruan.

Dengan memanfaatkan jaringan alumni dan guru Ponpes Sidogiri, maka para personil pondok pesantren tersebut lantas membentuk usaha gabungan terpadu (UGT) di Surabaya pada 2002. Pendirian BMT-UGT dimaksudkan memperluas jaringan BMT Sidogiri ke luar wilayah Pasuruan.

Satu dasawrsa lalu, berdasarkan ijin yang diberikan Dinas Koperasi Kabupaten Pasuruan, wilayah kerja BMT-MMU hanya sebatas Pasuruan.

Dialog No. 67 Tahun XXXII, Juli 2009129 
Saat ini, Koppontren ini telah mengajukan ijin mendirikan sejumlah BMT-UGT ke Dinas Koperasi \& PKM Jatim supaya dapat beroperasi di semua wilayah di Jatim. Sambutan masyarakat terhadap kehadiran BMT-UGT di Surabaya disebutkan cukup positif, dan kini berhasil menjaring 1.300 orang penabung dengan perputaran dana Rp4 miliar per bulan. Sebagian besar nasabahnya adalah pedagang besi rongsokan.

BMT-UGT Sidogiri memiliki produk pembiayaan simpan pinjam pola syariah dengan menerapkan lima akad meliputi: mudharabah/bagi hasil, musyarakah/penyertaan modal, murabahah/jual beli, bai'bitsamanil'ajil/ jual beli dan qord al hasan/hutang. Produk lainnya adalah tabungan yakni mudharabah umum, pendidikan, Idul Fitri, qurban, walimah, ziarah dan mudharabah berjangka atau deposito. Produk lain yang diandalkan BMT-UGT Sidogiri adalah jasa layanan transfer yakni layanan pengiriman uang bagi masyarakat penabung maupun bukan penabung melalui cabang kantor Koperasi BMT-UGT setempat kepada santri yang tengah menempuh pendidikan. Koperasi BMT-UGT telah memiliki 39 unit layanan di seluruh kabupaten/kota di Jatim, dan pada 2010 ditargetkan bertambah menjadi 100 cabang.

Omzetnya pun mengalami peningkatan dari tahun ke tahun, dimana pada 2005 senilai Rp43 miliar naik menjadi Rp89 miliar pada 2006 dan tahun lalu tercapai Rp180 miliar lebih. Peningkatan omzet diikuti peningkatan aset yang tercatat Rp13 miliar pada 2005 lantas naik menjadi Rp30 miliar pada 2006 dan tahun lalu mencapai Rp51 miliar. Dengan didukung jaringan alumni Ponpes Sidogiri sebanyak 30.000 orang lebih, hingga akhir 2007 koperasi tersebut memiliki anggota 216 orang anggota biasa dan luar biasa ditambah 28.987 orang berstatus calon anggota.[] 
Abd ar-Rahman ibn Khaldun, al Muqoddamah (TunisL al Daru al Tunisiyatu li al Nasyri).

Adi Sasono, 1999, Pemberdayaan

Ekonomi Rakyat Menuju Indonesian Baru, Cidesindo, Jakarta.

Alifan, dkk (penghimpun), Kemiskinan Struktural: Suatu Bunga Rampai (Jakarta: Yayasan Ilmu-Ilmu Sosial, cetakan I, 1980),

Deliar Noer, Mohammad Hatta: Biografi Politik (Jakarta: LP3ES, cetakan kedua, 1991).

Dj.A.Simarmata, Reformasi Ekonomi, Menurut Undang-Undang Dasar 1945:

Kajian Ringkas dan Interpretasi Teoritis (Jakarta: Lembaga penerbit Fakultas Ekonomi Universitas Indonesia, 1998).

Mohammad Hatta, Ekonomi Terpimpin (Jakarta: Penerbit Mutiara, 1979).

Mohammad Hatta, Beberapa Fasal Ekonomi: Djalan Ke Ekonomi dan Pembangunan (Djakarta, Dinas Penerbitan Balai Pustaka, Tjetakan keenam, 1960).

Mohammad Hatta, Daulat Rakyat, Tahun ke III, No. 79, 20

November, tahun 1933

Mubyarto, 2003, Membangun Sistem Ekonomi, BPFE, Yogyakarta.

Perkins, John, 2006. Confessions of an Economic Hit Man.

Profil Koperasi Pondok Pesantren Sidogiri (Koppontren Sidogiri) Kabupaten Pasuruan Jawa Timur, 2002
Revrisond Baswir (2004): Drama Ekonomi Indonesia: Belajar Dari Kegagalan Orde Baru. Penerbit: Kreasi Wacana, Yogyakarta

Triono, Dwi Condro. Bahaya Ekonomi Neo-Liberal di Indonesia. Media Politik dan Dakwah Al Wai'e. No. 57. Tahun V. Mei 2005.

Sritua Arif, 1998, Pembangunisasi dan Ekonomi Indonesia: Pemberdayaan Rakyat dalam Arus Globaliasi, Pustaka Zaman, Jakarta.

Sri Edi Swasono, 1998, Demokrasi

Ekonomi: Komitmen dan Pembangyunan Indonesia, (makalah pengukuhan sebagai gurtu besar Fakultas Ekonomi Universitas Indonesia), Juli 1998 Jakarta.

Sri-Edi Swasono, Indonesia is Not for Sale : Sistem Ekonomi Nasional Untuk Sebesar-besar Kemakmuran Rakyat, Demokrasi Ekonomi- Ekonomi Kelembagaan (Jakarta: Badan Perencanaan Pembangunan Nasional, 2007).

Salim Siagian dalam Majalah Usahawan no 02 Th XXX Februari 2001

Tap MPR RI: 2003

UU No. 25 Tahun 2000 tentang Program Pembangunan Nasional (Propenas)

Zulkarnain, 2003, Membangun Ekonomi Rakyat: Persefsi Tentang Pemberdayaan Ekonomi Rakyat, Adicipta, Yogyakarta. 